Conradie, E. M. (2013). The God of life a counter-intuitive confession.

The Ecumenical Review, 65(1): 3-6

http://dx.doi.org/10.1111/erev.12023b

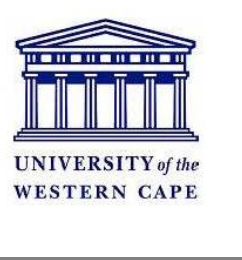

\title{
The God of life a counter-intuitive confession
}

\author{
Ernst Conradie
}

\begin{abstract}
In ecumenical theology the conviction that the triune God may be described as the "God of life" is widely accepted. This became foregrounded with the theology of life initiative of the World Council of Churches (WCC) in the 1990s ${ }^{1}$. It therefore comes as no surprise that it provides the central theme for the assembly of the WCC to be held in Busan, Korea, in 2013: "God of life, lead us to justice and peace." One may safely say that the wide acceptance of this phrase has to do with the recognition of the ethical significance of the theme. To emphasize that life belongs to God is to resist the forces of death and destruction. This is born from grassroots experiences of the threats to life, that is, economic injustices, numerous forms of violent conflict (rape, domestic violence, class struggles, colonial exploitation, civil and other forms of war, religiously infused violence, etc.) and environmental destruction. This calls for a Christian praxis of resistance against the powers of death that destroy communities of life for the sake of political and economic gain. A theology of life is therefore shorthand for affirming the social agenda of the ecumenical movement.
\end{abstract}

One may safely say that the wide acceptance of this phrase has to do with the recognition of the ethical significance of the theme. To emphasize that life belongs to God is to resist the forces of death and destruction. This is born from grassroots experiences of the threats to life, that is, economic injustices, numerous forms of violent conflict (rape, domestic violence, class struggles, colonial exploitation, civil and other forms of war, religiously infused violence, etc.) and environmental destruction. This calls for a Christian praxis of resistance against the powers of death that destroy communities of life for the sake of political and economic gain. A theology of life is therefore shorthand for affirming the social agenda of the ecumenical movement.

\footnotetext{
${ }^{1}$ See, among many other essays, Martien E. Brinkman, “A Theology of Life: Open Questions,” Exchange 24 (1995), 176-183; Wesley Granberg-Michaelson, “Towards a Theology of Life,” Reformed World 44 (1994), 99-110; Larry Rasmussen, “Theology of Life and Ecumenical Ethics," in Ecotheology: Voices from South and North, ed. David G. Hallman, pp. 112-129 (Geneva: WCC Publications, 1994); and Julio de Santa Ana, "Elements for a Theology of Life," Exchange 24 (1995), 159-175. See also my review of the literature: Ernst M. Conradie, "Eschatological Dimensions of a Theology of Life,” In Christian Hope in Context: Studies in Reformed Theology 4, ed. Aart van Egmond \& Dirk van Keulen, pp. 163-204 (Zoetermeer: Meinema, 2001).
} 
One may add that the theological significance of the theme is equally widely accepted in the context of faith and order discussions. This is partly related to the pneumatological turn in ecumenical theology first signalled by Konrad Raiser. ${ }^{2}$ Indeed, the Nicene affirmation that the Spirit is the giver of life has inspired many to retrieve notions of the Spirit of life. ${ }^{3}$ However, this is quite compatible with the biblical emphasis that life, indeed eternal life, is to be found through J esus Christ. This is signalled in the theme of the sixth assembly of the WCC held in Vancouver (1983): "J esus Christ the Life of the World." The phrase "God of life" may therefore be understood in a fully trinitarian way as referring to participation in the communal life of the triune God - as the social analogy preferred in the contemporary renaissance of trinitarian theology suggests.

The ecumenical consensus on the theological and ethical significance of a theology of life is such that the phrase "God of life" may be almost taken for granted even in contexts where the forces of death and destruction are all too obvious. In this contribution I wish to retrieve the counter-intuitive nature of the confession embedded in the phrase "God of life." I will do so in the form of ten observations by showing why it really cannot be taken for granted. My purpose in doing so is to retrieve the critical edge of this confession in order to understand its theological and ethical significance anew.

\section{WhatKind of Genitive?}

What does "God of life" actually mean? This is not immediately clear. Is it a descriptive genitive to characterize a particular kind of God, namely a living God, supposedly as opposed to dead idols? Or does the genitive indicate reference in this case, as in the phrase "a member of this congregation"? But how would this help to indicate which God is understood here? Or does it indicate possession in the sense that God belongs to life, that God is in service of life - as opposed to the "life of God," which would indicate the life belonging to God as God's inalienable possession (as in "this life of mine"). Or may it even be regarded as a partitive genitive in the sense that the notion of God forms part of life on earth? The last two options would be allowed in liberal or secular theology but cannot do justice to the Christian conviction that all of life comes from God and belongs to God.

What other options are available? The phrase is clearly not a subjective genitive in the way that "God of love" could be taken, namely as God's love for us. Nor is it an objective genitive in the sense that the phrase "God's love of life" could be read, unless it may be regarded as shorthand for the extended phrase. It cannot be taken as a genitive indicating origin either, since that would then have to mean that God comes from life (as in "people of Rome"), not that life comes from God. It is hardly a genitive indicating alienable possession (as in "the buildings of the church") or relationship (as in "the mother of J esus Christ").

\footnotetext{
${ }^{2}$ Konrad Raiser, Ecumenism in Transition: Paradigm Shift in the Ecumenical Movement? (Geneva: WCC Publications, 1991).

${ }^{3}$ See especially the pneumatological contributions by Jürgen Moltmann, The Spirit of Life: A Universal Affirmation (1992) and The Source of Life. The Holy Spirit and the Theology of Life (1997), both published by Fortress Press. See also Section 2 entitled “An Ethics of Life” in his recent Ethics of Hope (Minneapolis: Fortress Press, 2012), 45-108. Moltmann's contributions epitomize both the trinitarian focus and the ethical dimensions of a theology of life.
} 
In light of these alternatives, it may be best to regard it as a descriptive genitive, namely indicating that life is one of God's most salient characteristics. If so, it would still be better to suggest not only that it refers to a living God but that the most significant description of God's identity is that God is the One who is the origin of life, that God is the one to whom life belongs, and that God is the One who is the giver of (new) life. It should therefore be regarded as a somewhat cryptic phrase in which these core Christian convictions are embedded and integrated under the rubric of "life." This may do justice to the heart of the Christian confession, but is it plausible to say that? In the rest of this contribution I will seek to retrieve the radical and challenging nature of this confession by indicating how counter-intuitive it actually is.

\section{Where Does Life Come From? On the Origins of Species and of Life Itself}

The origin of life on earth remains one of the unresolved mysteries of contemporary science. The origin of species is, of course, the topic of evolutionary biology. The theological significance of the evolution of species through natural selection has been discussed in some detail in contemporary discourse on science and theology. ${ }^{4}$ However, this does not resolve the debate on the very origins of life itself. The building blocks of life can be analyzed in biochemistry. These can be described in the utmost detail in terms of the DNA of a species. However, the biological sciences tend to become reductionist on this point. Putting the cocktail of chemicals constituting life all together would not by itself yield life.

Where, then, does life itself come from? From "seeds of life" carried by asteroids? Is it perhaps the inevitable outcome of elements put together in a suitable environment - so that the conditions for life may be replicated elsewhere in the universe? Or is life the product of pure chance? To claim that life is the outcome of a careful blueprint or an intelligent design would raise questions about data gathered in evolutionary biology that suggest the process behind contemporary "designs" is far more complicated. Moreover, God as designer would then be held responsible for some faulty designs and the pain and suffering embedded in this design. ${ }^{5}$ Another alternative is to invite an interplay between intentional agency and chance, analogous to the intention of a couple to engage in sexual intercourse with a view to conception and having children of their own.

The unborn child is then fully intended but not designed according to some blueprint (which would be devilish), so that much of what family life might entail is left openended. Or is God perhaps the designer of the evolutionary process itself ? That may sound clever, but how on earth could Christians claim to have privileged revealed knowledge in this regard that is not accessible to the biological sciences?

Can one really say that God's revelation forms the basis of such knowledge? The Christian confession that the origin of life is indeed the God of life is therefore counterintuitive, to say the least. Given the immense work done in the biological sciences on the

\footnotetext{
${ }^{4}$ Amongst the countless contributions, see especially John F. Haught, God after Darwin: A Theology of Evolution (Boulder: Westview Press, 2000).

${ }^{5}$ See, for example, the critique of notions on intelligent design in Ted Peters and Martin Hewlett, Evolution from Creation to New Creation: Conflict, Conversation and Convergence (Nashville: Abingdon Press, 2003), 97-114.
} 
origins of life, is such a claim not all too arrogant? If we were not there in the beginning, how can we really know that? Who told us so? Did the Bible tell us so? How did the authors of the Bible know that, since they were not there in the beginning either? To maintain that the phrase "God of life" is a descriptive genitive saying something about God as the origin of life therefore requires further clarification.

\section{God as the Deepest Mystery of the World?}

The origin of life is only one of the profound mysteries that defy ready-made answers. I suggest that one may identify five sets of questions that human beings cannot help but ask but cannot answer in any final way - either through science, the arts, philosophy, or religion. ${ }^{6}$ One of these questions has to do with origins - with the origin of my life, the human species, life on earth, and the universe itself. Another has to do with destiny - the destiny of my life, my lineage, my culture, the human species, the earth, and the universe. Then there are questions regarding identity and vocation: What is the place and vocation of humans in the community of life? What is my role within that? Other questions have to do with movement - with causation and purpose amidst the uncertainty of the future. What makes the world go round?7 Is it luck, fate, or determinacy (law)? Is it love or the love of money that makes the world go round? How can I discern the direction of the wind in order to set my sails to that wind? How can one discern the signs of the time? Finally there are questions about pain, suffering, injustices, and evil: What is the ultimate source of suffering and how can victory over such evil be secured? If human beings have to raise these questions but cannot answer them, it is also true that we have to answer them - for better or for worse. Moreover, the answers that we do give matter; they shape our way of living every day of our lives. But do these answers still make sense to ourselves and to others?

Somewhere in early human history, notions of the divine emerged that offered a single answer to all these questions. God could be regarded as the origin and destiny of the world, the reference point for human existence, the one who governs all movements, and indeed the ultimate power to overcome suffering. This last aspect may well have been primary. In order to address uncertainties over the future in terms of rain and food, fertility, military battles, or enmity, the help of divine beings could be solicited to influence what lies beyond one's locus of control. One may find a widening scope of the sphere of influence of such a divine being - from a clan, a tribal, and a national god to one who transcends the known universe itself.

Such a notion of the divine may be regarded as a conjecture, a wager on transcendence, perhaps as the social construction of ultimate reality. But is it also more than that - as Christians and others claim? If so, how can we know that? Is the answer really revealed to us? A reminder may be appropriate that plausible answers to such questions, including questions about origins, cannot be provided by science either. There are not that many answers available to questions about the ultimate origins of the world and of life. It may

\footnotetext{
${ }^{6}$ I explored this set of questions in my inaugural lecture. See Ernst Conradie, "The Earth in God's Economy: Reflections on the Narrative of God's Work,” Scriptura 97 (2008), 13-36.

${ }^{7}$ See my recent essay in response to this question: Ernst M. Conradie, "What Makes the World Go Round? Some Reformed Perspectives on Pneumatology and Ecology,” Journal of Reformed Theology 6 (2012), 294-305.
} 
be a matter of randomness, necessity, the interplay between these, or of intentional agency. Either way, the extraordinary Christian claim that life comes from a divine being (the triune God in particular) and remains in God's hands cannot be taken for granted.

\section{Is God Subject to Change?}

To suggest that God is the God of life may be widely accepted in ecumenical circles nowadays but indicates a counter-intuitive notion of transcendence. One may argue that the very notion of God emerged on the basis of the need for a transcendent reference point to indicate the ultimate origin and destiny of the universe, an unmoved mover beyond the dimensions of space and time. If the divine has to provide a reference point for human identity and vocation, it could not be regarded as one living being amongst others. If the divine being is to be able to assist humans with overcoming pain and suffering, the divinity should preferably not be subject to the causes of pain (as all known living beings with a central nervous system are). If the divinity is to affect change, it should not be subject to change. A divine being should provide a sense of stability amidst the fluctuations of time, uncertainty, and human moods.

To affect salvation within the world, a divinity should of course be able to act within the world. Hence, there is a need for immanent notions of transcendence. Yet, as the Greek philosophers realized, a living God would be subject to change and could be regarded all too easily as one living being alongside others. The divine being should thus be infinite, immutable, impassionate, and eternal, but also omniscient, omnipotent and omnipresent. These characteristics do not apply to living beings, so that it is indeed counter-intuitive to speak of a living God. A God of life could also be taken to mean a God who produces, promotes, and supports life, but it should come as no surprise that the kind of life supported by a divine being is then understood as eternal life. This raises the question how the relation between time and eternity is to be understood. Is eternal life understood as a response to mortality, to transience, or to the unfulfilled, unlived moment? ${ }^{8}$ These questions need not and cannot be answered here. Suffice it to say that the phrase "God of life" should not be accepted and domesticated too soon. Philosophically it may actually be regarded, at least in some schools of thought, as a contradiction in terms.

\section{AGodWhoIntroduced Painand Suffering?}

If God is indeed the God of life, God is also the one who brought about the pain and suffering associated with all forms of conscious and self-conscious life. This is not merely to put the classic theodicy problem: Why does a loving God who is able to help and knows about (human) suffering not alleviate suffering caused by injustices and evil? In principle, suffering resulting from the evil consequences of sin can indeed be addressed if the roots of such evil (sin) can be overcome. This is to pose the problem of natural suffering widely discussed in contemporary debates on science and theology. ${ }^{9}$

\footnotetext{
${ }^{8}$ In his recent Ethics of Hope (2012) Moltmann rightly observes that we cannot conceive of timeless life. Instead, he affirms that "eternal life means the perfect fullness of life in unhindered participation in the life of God" (58). Does this mean more than living life to the fullest here and now in God's presence?

${ }^{9}$ Amongst many other contributions, see Haught, Theology after Darwin; Ruth Page, God and the Web of Creation (London: SCM Press, 1996); and especially Christopher Southgate, The Groaning of Creation: God, Evolution and theProblem of Evil (Louisville Westminster John Knox Press, 2008). For South African discourse in this regard, see
} 
Pain, degeneration, and mortality are built into the biological structures of all forms of life. Cells are pre-programmed to die and to be replaced. Pain offers an evolutionary advantage in the evolution of species. Sickness and mortality was part of the world long before there were human beings. If the metaphoric leaves fell from the trees in the Garden of Eden, degeneration and death formed part of God's good creation. ${ }^{10}$ All of these predicaments are exacerbated by injustices, but the underlying problem of natural suffering remains. If God is the source of life, God is also the source of pain. That would be appropriate for a demonic torturer, but hardly for a God of love. Put provocatively: How dare God then declare creation to be good? Moreover, can the Creator of pain somehow overcome pain? Can God do so through being subjected to pain? How can one make sense of that?

\section{Which God Are We Talking About?}

The contemporary recognition of the need for and the value of dialogue with other living faiths should not blunt our senses for the contestation between religious traditions that is so evident in the biblical roots of Christianity. In the study of religion, the rough equality of religious traditions has to be accepted in order to use the general rubric of "religion." The study of theology assumes that not just any religion will do. ${ }^{11}$ History is littered with examples of dangerous forms of religion. This is exemplified by the history of Christianity: not any form of Christianity will allow life to flourish. Likewise, not just any notion of the divine would help one to find plausible answers to the mystery of life.

In the interpretative trajectories that constitute the biblical roots of Christianity, a very particular understanding of God's identity and character gradually emerged. While all religious traditions were seeking a powerful God who could help to secure favourable outcomes (especially around fertility) and to overcome various threats (especially the power of evil), a notion of God emerged that suggests that the God of Israel is theGod of the powerless, of underdogs, of runaway slaves, of small bands fighting huge armies, of an unlikely hero fighting the giant Goliath, of widows and orphans, of the poor and the oppressed, the marginalized and the helpless, of justice and mency. ${ }^{12}$ This is epitomized in the ministry of J esus of Nazareth, who portrayed himself as standing in the tradition of the despised and rejected "suffering servant". For him, apparently, the power of rulers is demonstrated by serving the weak. That is counter-intuitive to say the least. Moreover, the Christian conviction is that this offers the best picture of God's identity and character. To maintain that J esus Christ is fully divine is not only saying something about him; it is also saying something about God. This core intuition provided the source of inspiration amidst the Christological and trinitarian debates of the patristic period. Yet it proved to be so

Cornel W. du Toit, ed., Can Nature be Evil and Evil Natural? A Science-and-religion View on Suffering and Evil (Pretoria: Unisa Press, 2006).

${ }^{10}$ This metaphor is derived from Arnold van Ruler. See for example his Van Schepping tot Koninkryk, ed. Gijsbert van den Brink and Dirk van Keulen (Barneveld: Serie Klassiek Licht, 2008), 301.

${ }^{11}$ I need to note that am I situated in a Department of Religion and Theology. If the above holds, these two disciplines may well be in conflict with each other. Perhaps that is why we also teach courses in Ethics - to keep the peace between the study of religion and of theology!

${ }^{12}$ My observations here are styled after Michael Welker, God the Spirit (Minneapolis: Fortress Press, 1994). On the notion of interpretative trajectories, see Klaus Nürnberger, Theology of Biblical Witness: An Evolutionary Approach (Hamburg: LIT Verlag, 2002). 
perplexing that ecclesial powers all too often embodied the opposite inclination by domesticating the gospel, by covering the cross with gold and silver, by structuring examples of holiness that replicated secular power structures.

The issue here is not merely that a kenotic principle yields a counter-intuitive politics and social ethics. ${ }^{13}$ Once God's identity is so narrowly articulated in the confession of faith in the triune God, this radicalizes the question how this triune God could be regarded as the ultimate mystery of the origin and destiny of the world. This is the scandal of particularity. How dare one think that the master of the universe (to adopt the J ewish phrase) could be identified on this small but beautiful planet, by the human species alone, only now after 4.6 billion years of the earth's history, specifically two thousand years ago, in an obscure province of the Roman empire, best understood with reference to an itinerant carpenter who died young, without children or money, with no writings of his own, dropped during his own lifetime by all his closest followers?

\section{How Does One Know This Anyway?}

This line of inquiry implies the need to return to the question: How did Christians arrive at this confession? How do Christians know that this triune God is the source of life, the giver of (new) life, the God of life? How do we know that this God is the Creator if we have not been there in the beginning? This is not merely a historical question but one that challenges the plausibility of the confession to insiders and outsiders alike.

This leads us to the heart of creation theology. In a way the question is: What is the appropriate question. Is the question whether the world (read life) was indeed created? Or when and how it was created? Or who created it (in line with the doxological tone of the biblical texts)? Or what was created? ${ }^{14}$ Or why it was created?

In my view, a more fruitful approach is to recognize that the word "creation" offers one possible interpretation, a re-description, and an ascription of the world as we think we know it. This reinterpretation of the world suggests that the world belongs to God, comes from God, and remains in God's hands. The same applies to life: Life comes from God, belongs to God, and lies within God's hands.

\footnotetext{
${ }^{13}$ In my view the current appreciation of the notion of kenosis that regards it as a cosmic principle underplays the historical contingency of the cross as God's response to human sin that is itself contingent (not necessary or inevitable). See George F. R. Ellis and Nancey Murphy, On the Moral Nature of the Universe (Minneapolis: Fortress Press, 1996); John Polkinghorne, ed., The Work of Love: Creation as Kenosis (Grand Rapids: WB Eerdmans, 2001).

${ }^{14}$ This may sound odd for some, but it is crucial to acknowledge that we do not know what God created. Firstly, we were not there in the beginning. Secondly, the world is subject to evolutionary change. Thirdly, in Christian terms the world as we experience it has been shaped both by the impact of sin and by the history of salvation. Finally, our knowledge of God's creation is also distorted by sin and formed by God's work of salvation. In fact, claims to know what God has created have had a disastrous track record to justify slavery and patriarchy, to assert the superiority of the Aryan race, to legitimize apartheid, and to demonize people on the basis of sexual orientation. Instead, we need to affirm that any notion of what God created is based on a contemporary reconstruction that is shaped by our views of what might have been God's original intentions. Indeed, it is more a matter of a vision for the future that has never been than a description of the distant past. Likewise, the myth of paradise is actually a dream for the future retrojected into the past.
} 
This re-description is certainly counter-intuitive in light of the above. How could one say that this world, with all its misery, comes from a loving God? How do we know that it is created and not the product of law, chance, or an evil complot? How do we know that this triune God is the Creator? Faith in God as Creator is therefore even less obvious than faith in God as Saviour and offers no common ground with others. Accordingly, the priority of faith in God as Creator should be inversed. Once God is known as the God of holy love, it is far from evident that this God would also be the Creator since the world as we know it does not necessarily reflect such love. ${ }^{15}$

Nevertheless, the significance of this re-description of the world should not be underestimated. To see the world as God's creation is very different from seeing nature in a romanticized way as a source of beauty and inspiration (for the leisured classes only), as red in tooth and claw (inviting a struggle for the survival of the fittest, also amongst humans), as nothing but real estate (allowing for industrial exploitation), or as so sublime that it needs to be worshipped. ${ }^{16}$ The same applies to the re-description of life suggested by the phrase "God of life." It counters both nihilist and hedonist views of life. It also questions anthropocentric views of humanity as the crown of evolution (if God is the God of all life) and modernist temptations to view humanity as autonomous, selfsufficient, or self-explanatory.

However, the question remains whether this re-description and ascription of the world as belonging to God is indeed plausible. I will explore this question from three further perspectives, in line with the trinitarian heart of the Christian confession.

\section{Life in the Household of the Father}

The image of God as Father is so well-established in the Christian tradition that its counter-intuitive nature is no longer recognized. The problem is not primarily associations with fertility cults, where the male sperm or the female womb may serve as analogies for thinking about the divine being as the giver of life. Instead, the conceptual shift is recognized only once God is confessed to be the "master of the universe," the Creator of heaven and earth, of what is visible and what is invisible. Such a divine being, if pictured through human imagery, would best be understood as analogous to a king or an emperor who rules over the whole universe with wisdom, majesty, and awesome power. Such a divine being would be distant, untouchable, hardly approachable, although contemporary images of royalty hardly suggest such majesty.

By stark contrast, the Pauline image of God as Father is one who is very much approachable, called by the intimate name "Abba" (Rom. 8:15). Moreover, this is a right afforded to former slaves, strangers, and aliens who were adopted as children and heirs in the Father's household (Eph. 2:19). This is a Father who does not want or need slaves but who seeks the reciprocity of children. The father in the parable of the prodigal son is unparalleled in human history. The question asked by the younger son is unheard of.

\footnotetext{
${ }^{15}$ This is for example the argument developed in the creation theology of Hendrikus Berkhof, Christian Faith: An Introduction to the Study of the Faith (Grand Rapids: WB Eerdmans, 1986).

${ }^{16}$ See the discussion of various "warped views" of nature as identified and described by Howard A. Snyder, Salvation Means Creation Healed: The Ecology of Sin and Grace (Eugene: Cascade Books, 2011), 42-45.
} 
Kenneth Bailey reports that he raised this question in traditional villages all over the Arab world: Have you ever heard of someone who asked what this son had asked? The answer was consistently negative. Indeed, it was regarded as an intolerable question because it implies that the son longs for the death of the father. Bailey reports two exceptions. In one case the father died heartbroken by the son's audacity. In the other case the son was chased away by his father who no longer wanted such a son. This makes the response from the father all the more remarkable. He does what no patriarch could be conceived of doing by allowing the son the freedom to reject his father. The father's response is one of awaiting the son's coming home. Indeed, this is a father with a difference. ${ }^{17}$ It suggests a direction that could easily be extrapolated in contemporary times to speak of God also as the Mother of life.

Such imagery is not only counter-intuitive; it is also highly attractive, sketching the parameters of a new dispensation. The ecumenical root metaphor of the whole household of God has been widely employed to fathom the kind of hospitality embedded in this parable. The ethical implications for the place of slaves, children, women, and other animals in God's household have been gathered in numerous contributions on justice, peace, and the integrity of creation. These points of convergence on the social agenda of churches were integrated towards a theology of life. This household is one in which the community of life can flourish - although one may still wish to raise questions about the slaughtering of the fattened calf.

If such imagery is attractive, one may still wonder about its plausibility in the $21^{\text {st }}$ century. Can this parable help us to offer resistance against consumerist and hedonist greed? Can such magnanimous hospitality overcome the alienation of so many groups in the whole household of God? Does it really offer a model for sustainable communities amidst population increases and food shortages?

\section{Abundant Life through Christ's Death?}

The affirmation of life in the household of the Father is more counter-intuitive than may be apparent. Throughout its history, the Christian tradition had to struggle with a denial of that which is worldly, earthly, bodily, and material. As the Canadian theologian Douglas J ohn Hall observes, there remains a need to counter a form of Christianity that is docetic, idealist, and world-denying, and that retains the abiding Hellenistic suspicion, perhaps even the Manichaean disdain, for matter. ${ }^{18}$ Drawing on Dietrich Bonhoeffer, he urges that the world must not be prematurely abandoned. For Hall, the incarnation and the cross symbolizes God's affirmation of the worth of the world (kosmos). This implies an affirmation of the material and finite creation, with all the vulnerability that entails. ${ }^{19}$ Indeed, it is worth so much to God that it is worth dying for (J ohn 3.16). Hall says, "This world, for all its pain and anguish of spirit, in spite of its injustice and cruelty, the deadly

\footnotetext{
${ }^{17}$ See the discussion on the father of the two lost sons by Kenneth Bailey, Poet \& Peasant: Through Peasant Eyes (Grand Rapids: WB Eerdmans, 1983), 158-206.

${ }^{18}$ See Douglas John Hall, The Steward: A Biblical Model Come of Age (Grand Rapids: WB Eerdmans, 1990$), 255$.

${ }^{19}$ Douglas John Hall, Professing the Faith: Christian Theology in a North American Context (Minneapolis: Fortress Press, 1993), 311.
} 
competition of the species and their never wholly successful struggle to survive - this world is the world for which God has offered up his 'only begotten Son.' "20

This core of the Christian confession is remarkable for several reasons. Firstly, there is the affirmation of what is vulnerable, fragile, and transient. Secondly, why would the Creator of evolution be concerned about the survival of the weak? Thirdly, there is the kenotic wisdom of self-sacrifice. This yields the Christological paradox: How could life be worth dying for? Fourthly, it should be noted that it is precisely the lives of perpetrators, of those who destroy the lives of others, whom Jesus was willing to die for. It may be difficult enough for the cultured despisers of religion to affirm the dignity of the oppressed, but for a persecuted Messiah to affirm the dignity of the imperial oppressors is much harder and far less palatable. One may suggest that the ministry of Jesus of Nazareth focused on oppressed peasants who oppressed and marginalized others so that the moral fabric of society unravelled. They were victims, but hardly as innocent as the poor are sometimes romanticized to be. He called them to conversion and regeneration, to new life in Him in whom there is abundant life (J ohn 10.10). Finally, the mystery remain that those who believe in Him may not perish but have eternal life (again J ohn 3:16). What on earth could that mean?

\section{The Renewal of Life through the Spirit}

According to the Christian confession, the Holy Spirit is the giver of life. This is not only to be understood in terms of creation in the beginning (ex nihilo?). The Spirit is also the one who nourishes weak life amidst the forces of death and destruction so that it can flourish. This is hard to believe amidst the overwhelming forces that relentlessly drive the current global economic order. Moreover, the Spirit breathes new life into situations that have come to a dead-end. In Christian soteriology this is termed regeneration (palingenesis). For example: Where can a new beginning be found when relationships have become stale, stagnated, and distorted? The Christian confession suggests that reconciliation is possible through the forgiveness of sins. The South African Truth and Reconciliation Commission demonstrated the remarkable power of such forgiveness. ${ }^{21}$ However, two decades after democracy the country remains deeply divided in terms of class and race. Is the ministry of reconciliation in Christ still plausible in such a secular, multi-religious society? How would a new beginning emerge in such a context. ${ }^{22}$

The accounts of the resurrection of J esus Christ in the gospels even suggest that the Spirit brings forth new life from death. This may be easy to imagine in terms of natural cycles of recycling. However, what could the hope for eternal life mean? We now know that life on earth will come to an end in a few billion years from now when the sun becomes a supernova - if the planet does not become arid like Mars due to climate change long before that. Is the resurrection of life possible in this context? Is the hope for the resurrection of the dead - which is the work of the Holy Spirit - still plausible?

\footnotetext{
${ }^{20}$ Hall, Steward, 120.

${ }^{21}$ This is epitomized by Desmond Tutu, the chairperson of the TRC. See especially Desmond Mpilo Tutu, No Future without Forgiveness (London, et al.: Rider Books, 1999).

${ }^{22}$ I have explored this question together with postgraduate students at UWC in a recent unpublished paper, entitled "Reconciliation as one Guiding Vision for South Africa? Conceptual Analysis and Theological Reflection."
} 
Underlying all these questions there is deeper problem, namely to understand divine agency in the world. How does the Spirit act to bring new life? How does that relate to what we know from science about the laws of nature? How does Spirit shape matter? In brief, what is needed here is a non-reductionist but also non-interventionist notion of God's action in the world. This is elusive (to say the least) and the subject of major international conversations. ${ }^{23}$

At this point the ecumenical movement faces the challenge of reflection on the world of world views. Christians from mainline churches in secularized societies are vulnerable to reductionist accounts of the Spirit's movements. Christians from Pentecostal and indigenous churches elsewhere in the world emphasize healing, liberation, and exorcism as the work of the Spirit but tend to do so in ways that sounds interventionist in secular societies shaped by modern science. Given such intractable differences, can the Spirit breathe new life in the ecumenical movement?

\section{Conclusion}

To confess faith in the "God of life" despite all these ten caveats is by no means insignificant. It offers a very particular way of looking at the world with far-reaching ethical implications. In the context of ecological destruction, it suggests an appreciation for the fragility of life and a treasuring of life as God-given. In the context of growing economic inequalities and structural injustices, it affirms the lives of the weak and the vulnerable as precious for the quality of relationships in the "community of life." 24 This is also counter-intuitive, as those who are less vulnerable are typically inclined to think that they do not need others. Accordingly, the poor need the rich but the rich in their hubris assume that they do not need the destitute. In the context of gross violations of human rights (perhaps in the quest to secure access to scarce resources), it calls for the recognition of the dignity of human life and the integrity of creation, ${ }^{25}$ for a sense of symbiosis, for convivence, ${ }^{26}$ for peace on earth. All of these are widely recognized in the ecumenical movement, but there is always a need to retrieve the source of inspiration that guides such ethical concerns. In this essay, I have undermined an easy ecumenical consensus on the "God of life" - precisely in order to rediscover this source of inspiration.

\footnotetext{
${ }^{23}$ Amongst many other contributions see Robert John Russell, Nancey Murphy, and William Stoeger, eds., Scientific Perspectives on Divine Action: Twenty years of Challenge and Progress (Vatican City: Vatican Observatory Publications/ Berkeley: Center for Theology and the Natural Sciences, 2008); See also Denis Edwards, How God Acts: Creation, Redemption, and Special Divine Action (Minneapolis: Fortress Press, 2010).

${ }^{24}$ See Harvey Sindima, “Community of life,” Ecumenical Review 41:4 (1989), 537-551.

${ }^{25}$ See Ernst Conradie, "On the Integrity of the Human Person and the Integrity of Creation: Some Christian Theological Perspectives," in The Integrity of the Human Person in the African Context: Perspectives from Science and Religion, ed. Cornel W. du Toi, pp. 107-152 (Pretoria: Unisa Press, 2004).

${ }^{26}$ See Theo Sundermeier, “Convivence: The Concept and Origin,” Scriptura S10 (1992), 68-80.
} 